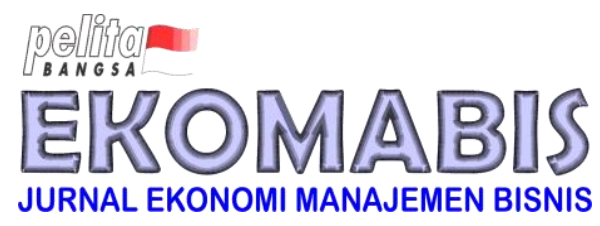

\title{
Determinan Pembiayaan Bagi Hasil Pada Perbankan Syariah
}

\section{(The Determinant of Profit Sharing Financing in Islamic Banking)}

Submit: 10 Jan $2021 \quad$ Review: 12 Jan $2021 \quad$ Accepted: 19 Jan $2021 \quad$ Publish: 27 Jan 2021

\section{Yuridistya Primadhita ${ }^{1}$; Anggraita Primatami2 ${ }^{2}$ Susilowati Budiningsih ${ }^{3}$}

\begin{abstract}
ABSTRAK
Pembiayaan bagi hasil bank syariah terbagi dalam bentuk pembiayaan mudharabah dan musyarakah yang didasarkan pada skema profit sharing atau revenue sharing. Skema ini sangat berbeda dengan kredit pada bank konvensional yang berbasis bunga. Tujuan penelitian adalah untuk menganalisis pengaruh dana pihak ketiga (DPK), financing to deposit ratio (FDR), dan non performing financing (NPF) terhadap pembiayaan bagi hasil perbankan syariah di Indonesia. Penelitian terdiri atas 37 observasi meliputi periode September 2017 sampai dengan September 2020. Data dianalisis dengan metode regresi linier berganda. Penelitian menghasilkan temuan DPK dan FDR berpengaruh positif terhadap pembiayaan bagi hasil, sementara NPF berpengaruh negatif terhadap pembiayaan bagi hasil. Semakin rendah risiko bank, semakin tinggi pengumpulan dana nasabah, dan semakin besar rasio penyaluran pembiayaan berpengaruh terhadap peningkatan penyaluran pembiayaan berbasis bagi hasil pada perbankan syariah di Indonesia.
\end{abstract}

Kata kunci: dana pihak ketiga, pembiayaan bagi hasil, pembiayaan bermasalah, rasio pembiayaan, bank syariah

Kode JEL:

\begin{abstract}
1 Sekolah Tinggi Ilmu Ekonomi IPWI Jakarta; yuridistya13@gmail.com

2 Sekolah Tinggi Ilmu Ekonomi IPWI Jakarta; anggraitami@gmail.com

3 Sekolah Tinggi Ilmu Ekonomi IPWI Jakarta; susilowatisubud@gmail.com
\end{abstract}

Profit sharing financing in Islamic banks is divided into mudharabah and musyarakah financing which is based on a profit sharing or revenue sharing scheme. This scheme is very different from interest-based credit at conventional banks. This study aims to analyze the impact of third party funds (DPK), financing to deposit ratio (FDR), and non-performing financing (NPF) on the profit sharing financing of Islamic banking in Indonesia. The study consisted of 37 observations 
covering the period September 2017 to September 2020. Data was analyzed using multiple linear regression methods. The results of the study showed that TPF and FDR had a positif effect on profit sharing financing, while NPF had a negatif effect on profit sharing financing. The lower bank risk, the higher collection of customer funds, and the higher financing distribution ratio have an effect on increasing the distribution of profit sharing based financing in Islamic banking in Indonesia.

Keywords: financing ratios, Islamic banks, non-performing financing, profit sharing financing, third party funds

JEL Codes: .....

\section{Pendahuluan}

Memasuki usia 28 tahun, perbankan syariah saat ini berkembang dengan hadirnya 14 bank syariah umum (BUS) dan 34 unit usaha syariah (UUS). Kehadirian bank syariah merupakan solusi dari sistem perbankan konvensional yang menawarkan skema bunga dalam mengelola dana nasabah. Bank syariah menawarkan skema bagi hasil berdasarkan keuntungan atau pendapatan sesuai dengan prinsip syariat Islam (Hasan, 2015). Skema bagi hasil merupakan bentuk kerja sama yang terjadi antara pihak pemilik modal dengan pihak pengelola. Pembagian hasil atau keuntungan didasarkan pada nisbah atau bagian yang telah disepakati di awal. Sementara jika terdapat kerugian maka besarnya akan menjadi tanggungan bersama sesuai kesepakatan yang telah ditetapkan di awal (Suherman, 2017).

Bank syariah sebagai lembaga intermediasi keuangan berperan dalam mendorong peningkatan ekonomi riil di masyarakat. Total aset yang dimiliki perbankan syariah pada bulan September 2020 mencapai Rp 561,84 triliun, dimana rasio penyaluran dana atau financing to deposits ratio (FDR) perbankan syariah sebesar 77,06\% (OJK, 2020). FDR menggambarkan kemampuan bank syariah menyalurkan dananya kepada nasabah dibandingkan dengan dana yang diterima bank dari nasabah (Gunanto, et al. 2018). Pencapaian FDR ini masih lebih rendah jika dibandingkan loan to deposits ratio (LDR) yang dicapai perbankan konvensional. Pada periode yang sama, LDR perbankan konvensional tercatat sebesar 83,46\% (OJK, 2020). Pencapaian bank syariah ini menandakan peran intermediasi bank syariah melalui penyaluran pembiayaan masih dapat ditingkatkan dan dioptimalkan.

Pembiayaan yang dilakukan olah bank syariah pada dasarnya mencakup pembiayaan berskema jual beli, sewa, dan bagi hasil. Untuk pembiayaan jual beli, digunakan untuk kepemilikan barang dan pembiayaan sewa digunakan untuk memperoleh layanan. Sementara pembiayaan bagi hasil digunakan untuk usaha dengan melibatkan beberapa pihak. Pada pembiayaan bagi hasil, margin keuntungan yang didapat oleh bank bergantung pada keuntungan usaha yang dibagikan berdasarkan prinsip pembagian pendapatan (revenue sharing), dimana keuntungan dibagikan menurut rasio tertentu yang telah ditentukan dan 
sepakati sebelumnya. Perjanjian bagi hasil ini dilakukan dengan produk pembiayaan berakad musyarakah atau mudahrabah.

Pada awalnya, penyaluran pembiayaan perbankan syariah mayoritas adalah pembiayaan jual beli (murabahah). Namun dalam perkembangannya, pembiayaan bagi hasil melalui akad mudharabah dan musyarakah terus mengalami peningkatan. Pada September 2020, pembiayaan bagi hasil perbankan syariah tercatat sebesar $\mathrm{Rp} 181,72$ triliun, lebih tinggi jika dibandingkan pembiayaan jual beli yang sebesar $\operatorname{Rp~170,84~triliun.~Besarnya~}$ penyaluran pembiayaan ini dapat menjadi salah satu indikator penilaian kinerja perbankan syariah. Perbankan syariah juga perlu hati-hati ketika melakukan penyaluran pembiayaan, sehingga kualitas pembiayaan terjaga. Perbankan syariah harus mampu menjaga level pembiayaan bermasalahan atau non performing financing (NPF). Semakin tinggi NPF mengindikasikan menurunnya kualitas pembiayaan. NPF yang tinggi menandakan bank harus meningkatkan cadangannya dan hal ini dapat mempengaruhi terkikisnya modal bank (Indriastuti \& Kartika, 2018)

Pentingnya DPK, FDR, dan NPF dalam penyaluran pembiayaan bank syariah terlihat dari banyaknya penelitian terdahulu yang telah dilakukan. Gunanto, et al. (2018) menemukan bahwa FDR dan DPK berpengaruh positif pada pembiayaan musyarakah Bank Syariah Mandiri tahun 2010-2017. Hal ini sejalan dengan Indriastuti \& Kartika (2018) yang menemukan bahwa FDR dan DPK berdampak positif terhadap pembiayaan total bank syariah, sementara NPF tidak memiliki dampak signifikan. Widiastuty (2017) juga menemukan bahwa NPF tidak memiliki pengaruh terhadap pembiayaan bagi hasil. Sama halnya dengan Hasnadina \& Mulazid (2019) yang menemukan DPK, FDR, dan margin pembiayaan memiliki pengaruh positif terhadap pembiayaan jual beli (murabahah), sementara NPF tidak memiliki pengaruh. Tingginya NPF membuat bank lebih selektif ketika melakukan pembiayaan yang disalurkan sehingga dapat membawa dampak negatif pada penyaluran pembiayaan perbankan syariah.

Penelitian terdahulu umumnya membahas pengaruh DPK, FDR, dan NPF terhadap tingkat pembiayaan bank syariah dalam lingkup total pembiayaan. Sementara, tujuan penelitian ini secara khusus meneliti pengaruh DPK, FDR, dan NPF terhadap besarnya pembiayaan bagi hasil, yaitu pada akad mudharabah dan musyarakah. Fokus penelitian pada pembiayaan bagi hasil karena skema ini mengedepankan adanya sistem kerja sama dengan pembagian keuntungan atau pembagian pendapatan yang secara alamiah berperan mengoptimalkan pengembangan perekonomian masyarakat, terutama bagi sektor UMKM. Penelitian memasukkan faktor DPK karena faktor ini merupakan sumber utama dana pembiayaan, sementara faktor FDR menandakan seberapa besarnya fungsi intermediasi bank dalam menyalurkan pembiayaan ke masyarakat, sedangkan NPF menunjukkan sebesar besar kondisi pembiayaan bermasalah dari dana yang telah tersalurkan ke masyarakat. 
Penelitian ini bertujuan menguji hubungan kausalitas antar variabel independen terhadap variabel dependen berdasarkan teori dan penelitian terdahulu. Variabel independen yang digunakan terdiri atas variabel DPK, FDR, dan NPF. Variabel dependen berupa pembiayaan bagi hasil yang merupakan total pembiayaan akad mudharabah dan akad musyarakah.

\section{Metodologi}

\subsection{Pengembangan Model/Konsep}

Besarnya DPK yang menandakan ketersediaan dana yang dimiliki oleh bank. Semakin besar dana tabungan, giro, dan deposito akan semakin meningkatkan kemampuan bank menyalurkan pembiayaan. Hal ini terlihat dengan kenaikan tren penyaluran pembiayaan yang sejalan dengan tren kenaikan DPK (Adzimatinur et al., 2015). Dengan demikian, DPK diduga memiliki pengaruh positif terhadap pembiayaan $\mathrm{PBH}$.

H1: DPK berpengaruh positif terhadap PBH

FDR menggambarkan kemampuan bank syariah dalam menyalurkan pembiayaan kepada nasabah dibanding dengan dana yang diterima bank syariah dari nasabah (Gunanto et al., 2018). Semakin tinggi tingkat FDR menandakan semakin besar tingkat intermediasi bank.

H2: FDR berpengaruh positif terhadap $\mathrm{PBH}$

NPF menandakan situasi dimana nasabah tidak dapat membayar kewajibannya atau menjadi bermasalah. Meningkatnya nilai NPF menandakan turunnya kualitas pembiayaan perbankan dan tingkat kesehatan bank akan mengalami penurunan. Tingginya tingkat NPF akan menyebabkan bank syariah lebih berhati-hati dan selektif dalam menyalurkan pembiayaan (Indriastuti \& Kartika, 2018).

\section{H3: NPF berpengaruh negatif terhadap PBH}

$\mathrm{PBH}$ periode sebelumnya dapat mempengaruhi penyaluran $\mathrm{PBH}$ pada periode setelahnya. Hal ini terlihat pada penyaluran pembiayaan yang diberikan kepada nasabah yang memiliki rekam jejak pembayaran yang baik namun masih membutuhkan modal atau kepada nasabah baru yang memenuhi kriteria dan ketentuan bank (Priyanto et al., 2016).

H4: PBH(-1) berpengaruh positif terhadap PBH

Pengukuran variabel disajikan pada tabel 1. Dugaan hubungan antara variabel DPK, FDR, dan NPF dengan PBH dapat digambarkan dalam kerangka sebagaimana pada gambar 1 . 
Tabel 1. Operasionalisasi Variabel

Variabel/Konsep/Indikator

Skala

Dana pihak ketiga (DPK) mencakup seluruh dana dari simpanan

giro, tabungan, dan deposito dari nasabah atau konsumen non-

bank baik dengan akad wadiah maupun mudharabah (Indriastuti

Rasio

\& Kartika, 2018).

$D P K=$ giro + tabungan + deposito

Financing to deposits ratio (FDR) merupakan rasio seluruh

pembiayaan perbankan kepada pihak ketiga bukan bank dengan Rasio dana dari pihak ketiga (DPK) (Indriastuti \& Kartika, 2018).

$F D R=\frac{\text { Pembiayaan kepada pihak ketiga bukan bank }}{\text { Dana pihak ketiga }} \times 100 \%$

Non performing financing (NPF) adalah rasio yang menghitung

besarnya pembiayaan bermasalah dari seluruh pembiayaan

Rasio

perbankan (Widiastuty, 2017).

$N P F=\frac{\text { Pembiayaan kurang lancar, diragukan, dan macet }}{\text { Total Pembiayaan }} \times 100 \%$

Pembiayaan bagi hasil (PBH) mencakup seluruh penyaluran pembiayaan bank syariah kepada pihak ketiga bukan bank yang menggunakan akad mudharabah dan musyarakah (Widiastuty, 2017).

PBH(-1) merupakan pembiayaan bagi hasil periode sebelumnya

Rasio

Sumber: Teori dan diolah, 2020

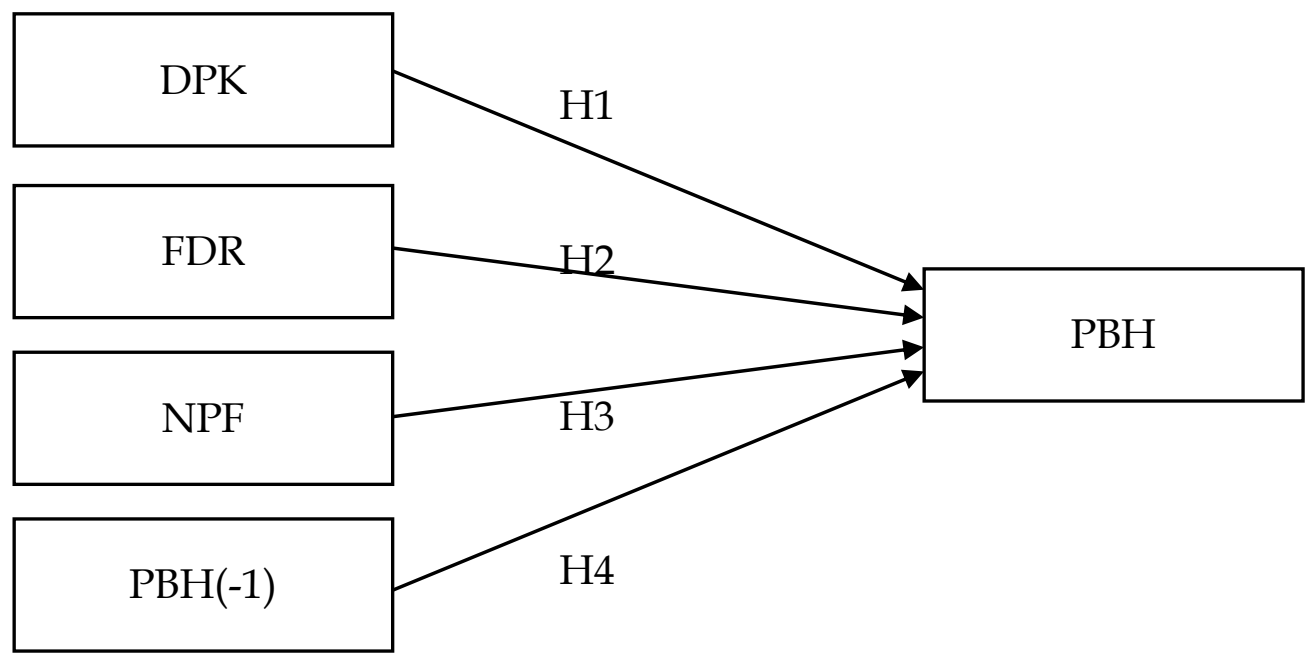

Sumber: Pengembangan model, 2020

Gambar 1. Kerangka Pemikiran 


\subsection{Metode Analisis}

Penelitian ini dilakukan dengan menggunakan data berbentuk sekunder perbankan syariah yang bersumber dari laporan Statistik Perbankan Syariah bulan September 2020 yang dikeluarkan oleh Otoritas Jasa Keuangan (OJK). Penelitian menggunakan data bulanan perbankan syariah periode September 2017 sampai dengan September 2020 yang terdiri atas 14 bank syariah umum (BUS) dan 34 unit usaha syariah (UUS). Selanjutnya, pengolahan data dilakukan dengan bantuan program Eviews 10.

Metode yang digunakan mencakup atas uji normalitas, multikolinearitas, heteroskedastisitas, dan autokorelasi. Setelah pengujian asumsi klasik, data diolah dengan pengujian regresi berganda untuk melihat pengaruh dari variabel DPK, FDR, NPF, dan PBH(-1) terhadap variabel PBH yang mencakup uji t, uji F, dan koefisien determinasi. Model pada penelitian ini menggunakan persamaan logaritma karena terdapat perbedaan dalam satuan variabel yang digunakan sebagai berikut:

$\ln P B H=a+b 1 \ln D P K+b 2 \ln F D R+b 3 \ln N P F+b 4 \ln P B H(-1)$

\section{Hasil}

Nilai korelasi antar variabel dependen $<0,7$ yang mencerminkan tidak terdapat masalah multikolinearitas terhadap variabel di dalam model penelitian. Selanjutnya, berdasarkan uji autokorelasi diketahui bahwa melalui uji BreuschGodfrey nilai probabilitas sebesar 0,6292 > 0,05 menandakan tidak adanya gejala autokorelasi dalam model penelitian. Hasil uji heteroskedastis dengan menggunakan metode white diketahui nilai probabilitas sebesar 0,7312 > 0,05 mencerminkan bahwa tidak terjadi gejala heteroskedastis dalam model penelitian. Kemudian dilakukan uji normalitas dimana diketahui nilai probability Jarque Berra sebesar 0,8913 > 0,05 mengandung artinya nilai residual data terdistribusi normal.

Nilai adjusted square $\left(\right.$ Adj $\left.R^{2}\right)$ diperoleh sebesar 0,9923 sebagaimana tabel 2. Nilai tersebut menunjukkan bahwa pembiayaan bagi hasil dapat dijelaskan 99,23\% oleh DPK, FDR, NPF, pembiayaan bagi hasil periode sebelumnya. Tingginya nilai adjusted square ini dapat dikatakan bahwa variabel DPK, FDR, NPF, dan pembiayaan bagi hasil periode sebelumnya merupakan variabel utama dari pembiayaan bagi hasil yang memiliki pengaruh besar.

Tabel 2. Koefisien Determinasi

\begin{tabular}{ccccc}
\hline $\mathrm{R}^{2}$ & Adj. R & F-stat & Prob (F-stat) & DW \\
\hline 0,9932 & 0,9923 & 1163,970 & 0,0000 & 1,820926 \\
\hline
\end{tabular}

Sumber: Data penelitian diolah, 2020 
Tabel 3. Hasil Uji Statistik

\begin{tabular}{cccccc}
\hline Variabel & Coefficient & Std. Error & $\mathrm{t}$ & Sig. & Hasil \\
\hline Constant & $-3,6414$ & 1,6072 & $-2,2658$ & 0,0304 & \\
LNDPK & 0,5492 & 0,1536 & 3,5748 & 0,0011 & H1 diterima \\
LNFDR & 0,4711 & 0,1918 & 2,4560 & 0,0197 & H2 diterima \\
LNNPF & $-0,1325$ & 0,0322 & $-4,1104$ & 0,0003 & H3 diterima \\
LNPBH(-1) & 0,5558 & 0,0953 & 5,8318 & 0,0000 & H4 diterima \\
\hline
\end{tabular}

Sumber: Data diolah, 2020

Hasil pengujian regresi linier berganda pada tabel 3 memperlihatkan bahwa nilai koefisien variabel DPK terhadap PBH sebesar 0,5492 memiliki nilai sig. 0,0011 sehingga H1 diterima karena signifikan. Nilai koefisien variabel FDR terhadap PBH sebesar 0,4711 memiliki nilai sig. 0,0197 sehingga H2 diterima karena signifikan. Nilai koefisien variabel NPF terhadap PBH sebesar -0,1325 memiliki nilai sig. 0,0003 sehingga H3 diterima karena signifikan. Nilai koefisien variabel PBH(-1) terhadap PBH sebesar 0,5558 memiliki nilai sig. 0,0000 sehingga H4 diterima karena signifikan. Berdasarkan pengujian regresi linier berganda dapat diketahui hasil sebagai berikut:

$\ln P B H=-3,64+0,55 \ln D P K+0,47 \ln F D R-0,13 \ln N P F+0,56 \ln P B H(-1) \ldots 2)$

\section{Pembahasan}

\subsection{Pengaruh Dana Pihak Ketiga (DPK) terhadap Pembiayaan Bagi Hasil (PBH)}

Hasil penelitian menunjukkan bahwa dana pihak ketiga (DPK) berpengaruh positif terhadap pembiayaan bagi hasil (PBH). Perubahan pada DPK sebesar satu persen dapat mengakibatkan meningkatnya $\mathrm{PBH}$ sebesar 0,55 persen. Temuan ini sejalan dengan penelitian Adzimatinur et al. (2015), Husaeni (2017), Indriastuti \& Kartika (2018), dan Primadhita \& Wicaksana (2020) yang menemukan pengaruh positif DPK terhadap pembiayaan perbankan syariah. Keberadaan DPK merupakan sumber bagi besar kecilnya pembiayaan yang tersalurkan ke masyarakat. Hal ini tercermin dari pola pertumbuhan DPK yang sejalan dengan pertumbuhan $\mathrm{PBH}$.

Semakin besarnya DPK akan berpengaruh pada semakin besarnya ketersediaan dana yang disalurkan dalam bentuk pembiayaan bagi hasil. Untuk itu hendaknya bank syariah harus terus melakukan peningkatan pengumpulan dana pihak ketiga. Namun demikian, sebagian besar dana pihak ketiga perbankan syariah masih didominasi oleh dana deposito yang berbiaya mahal. Pada September 2020, porsi deposito sebesar 52\% dari keseluruhan dana pihak ketiga yang dikelola perbankan syariah, sementara sisanya sebesar $48 \%$ berupa 
tabungan dan giro. Proporsi dana pihak ketiga juga hendaknya diarahkan pada memperbesar dana berbiaya murah yaitu tabungan dan giro. Dengan demikian, akan semakin memperbesar tingkat keuntungan bank.

\subsection{Pengaruh Financing to Deposits Ratio (FDR) terhadap Pembiayaan Bagi Hasil (PBH)}

Temuan penelitian adalah financing to deposits ratio (FDR) memiliki pengaruh positif terhadap pembiayaan bagi hasil $(\mathrm{PBH})$. Peningkatan FDR sebesar satu persen akan menyebabkan meningkatnya $\mathrm{PBH}$ sebesar 0,47 persen. Hasil ini sama dengan penelitian Adzimatinur et al. (2015), Husaeni (2017), Indriastuti \& Kartika (2018), dan Gunanto et al. (2018).

FDR dapat menggambarkan kondisi likuiditas bank syariah. Semakin tinggi tingkat FDR menandakan kondisi semakin besar nilai penyaluran pembiayaan. Kondisi saat ini FDR bank syariah masih lebih rendah dibandingkan dengan loan to deposits ratio (LDR) bank konvensional, menandakan bahwa masih memungkinkannya bank syariah meningkatkan penyaluran pembiayaan agar mencapai level yang optimal. Komposisi pembiayaan bagi hasil juga perlu dilakukan secara seimbang antara penyaluran kepada usaha besar dengan UMKM. Penyaluran PBH bank syariah saat ini masih didominasi oleh usaha besar, untuk itu ke depannya hendaknya perlu ditingkatkan penyaluran pembiayaan kepada sektor UMKM. Hal ini mengingat UMKM merupakan sektor penggerak ekonomi rakyat.

\subsection{Pengaruh Non Performing Financing (NPF) terhadap Pembiayaan Bagi Hasil (PBH)}

Temuan penelitian adalah non performing financing (NPF) berpengaruh negatif terhadap pembiayaan bagi hasil (PBH). Peningkatan NPF sebesar satu persen menyebabkan turunnya $\mathrm{PBH}$ sebesar 0,13 persen. Hasil ini sama dengan penelitian Adzimatinur et al. (2015). Temuan ini tidak sama dengan penelitian Widiastuty (2017) dan Husaeni (2017) yang menunjukkan bahwa NPF tidak mempunyai pengaruh yang signifikan terhadap $\mathrm{PBH}$.

NPF menunjukkan besarnya pembiayaan yang bermasalah terhadap keseluruhan pembiayaan. Ketika tingkat non performing financing meningkat akan menyebabkan bank syariah harus meningkatkan ketersediaan biaya penghapusan pembiayaan (write off) bagi pembiayaan-pembiayaan yang tidak tertagih. Hal ini akan menurunkan kualitas pembiayaan dan hal ini akan berdampak kepada kinerja bank syariah untuk melakukan penyaluran pembiayaan. Untuk itu, bank syariah hendaknya berfokus pada sektor usaha yang mengalami kinerja yang baik dan berkelanjutan. Pada saat ini, sektor usaha yang dapat dituju antara lain adalah sektor usaha di bidang informasi dan telekomunikasi, kesehatan dan pendidikan. 


\subsection{Pengaruh Pembiayaan Bagi Hasil Periode Sebelumnya (PBH(-1)) terhadap Pembiayaan Bagi Hasil (PBH)}

Temuan penelitian adalah pembiayaan bagi hasil periode sebelumnya $(\mathrm{PBH}(-1))$ berpengaruh positif terhadap pembiayaan bagi hasil (PBH). Peningkatan $\mathrm{PBH}(-$ 1) sebesar satu persen menyebabkan naiknya $\mathrm{PBH}$ sebesar 0,56 persen. Hasil ini sama dengan penelitian (Priyanto et al., 2016). Kondisi ini mencerminkan pembiayaan bagi hasil periode sebelumnya menjadi salah satu pengaruh penyaluran pembiayaan. Keputusan pembiayaan pada nasabah bergantung pada rekam jejak nasabah tersebut. Kinerja pembayaran angsuran yang tepat waktu menjadi pertimbangan nasabah tersebut bisa meningkatkan mendapatkan pembiayaan atau meningkatkan nilai pembiayaannya. Pembiayaan periode sebelumnya juga dapat dijadikan acuan sektor pembiayaan mana yang dapat memberikan keuntungan lebih besar bagi bank.

\section{Kesimpulan}

Penelitian ini menghasilkan kesimpulan bahwa semakin rendah risiko bank syariah yang diperlihatkan dengan rendahnya rasio pembiayaan bermasalah berpengaruh terhadap peningkatan pembiayaan bagi hasil kepada masyarakat. Sementara itu, semakin meningkatnya pengumpulan dana nasabah dan semakin besar rasio penyaluran pembiayaan berpengaruh terhadap peningkatan penyaluran pembiayaan bagi hasil. Dengan demikian, hendaknya risiko pembiayaan harus terus dijaga dengan cara selektif terhadap riwayat nasabah dan keberlanjutan sektor usaha nasabah. Pengumpulan dana juga hendaknya semakin ditingkatkan dengan menerbitkan produk-produk yang dapat meningkatkan simpanan masyarakat di bank syariah dan mudah diakses masyarakat serta meningkatkan layanan dengan mobile banking dan internet banking. Bagi penelitian selanjutnya hendaknya dapat menambahkan variabel seperti tingkat profitabilitas, tingkat capital adequacy ratio (CAR), dan juga faktor makro seperti inflasi, suku bunga dan pertumbuhan ekonomi.

\section{Daftar Pustaka}

Adzimatinur, F., Hartoyo, S., \& Wiliasih, R. (2015). Faktor-faktor yang memengaruhi besaran pembiayaan perbankan syariah di Indonesia. AlMuzara'ah, 3(2), 106-121. https:// doi.org/10.29244/jam.3.2.106-121

Gunanto, D. S., Suprihati, S., \& Aristi, F. W. (2018). Pengaruh financing to deposit ratio (FDR), dana pihak ketiga (DPK), dan return on asset (ROA) terhadap pembiayaan musyarakah. Jurnal Ilmiah Edunomika, 02(02), 219-230. https:// doi.org/10.29040/jie.v2i02.316

Hasnadina, P. S., \& Mulazid, A. S. (2019). Analyze the Effect of Third Party Fund (TPF), Non-Performing Financing (NPF), Financing To Deposit Ratio (FDR) and Profit Margin on Murabahah Financing of Sharia Commercial Bank. AlMasraf: Jurnal Lembaga Keuangan Dan Perbankan, 4(1), 17-27. 
https:// doi.org/10.15548/al-masraf.v4i1.227

Husaeni, U. A. (2017). Determinan Pembiayaan Pada Bank Pembiayaan Rakyat Syariah di Indonesia. Esensi, 7(1), 49-62. https:// doi.org/10.15408/ess.v7i1.4542

Indriastuti, M., \& Kartika, I. (2018). Factors That Affect The Financing Volume In The Sharia Commercial Banks. Trikonomika, 17(1), 38-42. https:// doi.org/10.23969/trikonomika.v17i1.894

Primadhita, Y., \& Wicaksana, I. (2020). Analisis economies of scale pembiayaan usaha mikro kecil dan menengah di perbankan syariah. Prosiding Manajerial Dan Kewirausahaan, 1-10. https://doi.org/10.33370/ prc.v4i0.452

Priyanto, T., Fahmi, I., \& Ismal, R. (2016). Faktor-faktor yang memengaruhi pembiayaan berbasis bagi hasil (equity financing) pada bank syariah $X$. Jurnal Aplikasi Bisnis dan Manajemen, 2(3), 281-290. https:// doi.org/10.17358/jabm.2.3.281

Widiastuty, T. (2017). Faktor-faktor yang mempengaruhi volume pembiayaan berbasis bagi hasil pada perbankan syariah di Indonesia. Jurnal Manajemen, 21(1), 90-103. https://doi.org/10.24912/jm.v21i1.149 